\title{
STUDY OF THE REACTION MECHANISM OF ASPIRIN AND GLYCINE
}

\author{
Hakan Sezgin Sayiner \\ Department of Infectious Diseases, Medicine \\ Adıyaman University, Adıyaman, Turkey
}

\author{
Fatma Kandemirli \\ Department of Biomedical Engineering \\ Kastamonu University, Kastamonu, Turkey
}

\author{
Fatma Aldibashi \\ Department of Material Science Engineering \\ Kastamonu University, Kastamonu, Turkey
}

\begin{abstract}
Many people take more than two drugs per day. These several drug regimens may result undesired effects known as drug-drug interactions (DDIs). DDIs effects can be physical, chemical or biological through complex interaction with different proteins. In this study, the interaction between aspirin which is the acetate ester of salicylic acid commonly used for minor aches as a pain reliever and glycine that is one of amino acids (AA) which is the basic building blocks of proteins. A density functional study was conducted by using B3LYP theory with the 6-31G(d, p) basis set and the possible mechanism of the reaction was investigated. It was found that the nitrogen atom belonging to glycine attacks the carbonyl carbon of aspirin and forms intermediate product via TS1 then undergoes a condensation to produce final products $\left(3+\mathrm{H}_{2} \mathrm{O}\right)$. The activation enthalpies of the reaction were also anticipated. The reaction was found to be slightly endpthermic. The reaction mechanisms of aspirin with glycine have been studied as stepwise mechanism.
\end{abstract}

Keywords - glycine, aspirin,. B3LYP

\section{INTRODUCTION}

Aspirin, or acetylsalicylic acid (ASA), is a nonsteroidal antiinflammatory and antipyretic drug. Since 1893, German chemist Felix Hoffman has encouraged Bayer to synthesis acetylsalicylic acid, patented as aspirin, non-steroidal antiinflammatory drug (NSAIDs), It have become the most widely advised and used drug. With this drug 5 to 10 billion dollars/year are spent by approximately 50 million people in the United States alone [1].

It is commonly used as a pain reliever for minor aches and pains as a pain reliever and alleviation of fever [1]. It is also used as a blood thinner in low doses to help prevent clots of blood and heart attacks [2]. Acetylsalicylic acid (ASA) is the aspirin generic term Figure 1.<smiles>CC(=O)Oc1ccccc1C(=O)O</smiles>

Figure 1. Aspirin (Acetylsalicylic acid ASA) chemical structure

The main aspirin metabolite is salicylic acid which is an integral part of human and animal metabolism [3] Before 1971 the real mechanism of action of aspirin-like drugs was a little known. They provided an anti-inflammatory effect that was quantitatively and qualitatively unlike that of the antiinflammatory steroids. A lot of biochemical actions of aspirin like drugs have been recorded and theories based on these actions have been unoccupied. It was noted that dehydrogenase enzymes were inhibited by several salicylates. Several salicylates also inhibited some aminotransferases and decarboxylase, as were plenty of key enzymes associated with protein and RNA biosynthesis [4].

In 2014 Murtaza and coworkers studied the effect of amino acids on the solubility of aspirin. This study indicated that with accompanying administration of amino acids the solubility of aspirin increases. They concluded that low of aspirin dose should be recommended when the use of amino acids (portentous foods) with aspirin should be prohibited [5].

In 2015 Wang and coworkers studied the effects of aspirin on inhibition of protein synthesis, and they identified 8 different amino acid residues that are modified by aspirin: tyrosine, serine, lysine, histidine, arginine, threonine, cysteine and tryptophan, their study was the first study reported the aspirin modification on other amino acid residues. They concluded that about $82 \%$ of the modified residues were lysine. These aspirin targeted proteins in their study are appeared in various cellular processes [6].

Amino acids (AA) are organic compounds that contain the basic amine group, $\mathrm{NH}_{2}$ and acid carboxyl group, $\mathrm{COOH}$. Essentially, AA are coupled together by peptide bonds to form 
the basic structure of proteins. AA are categorized into varying ways based on nutritional requirement, structure, metabolic fate, and polarity.

Mainly used categorized is based on polarity. The AA are classified depending on the basis of polarity to: polar AA with no charge, polar AA with negative charge, polar AA with positive charge and non-polar AA. Non-polar AA are neutral (R-group is uncharged), possess equal number of amino and carboxyl groups and hydrophobic.

Glycine Figure 1, which is one of our title compounds, is one of the amino acid in this group [5]

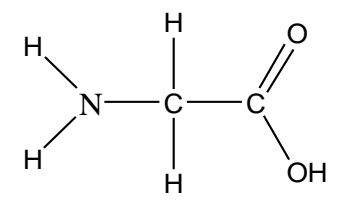

Figure 2 Glycine (Amino acid) chemical structure.

The peptide bond being of central importance in biological chemistry in general and protein chemistry in particular. The bond that formed between amino group and carboxyl group being of central importance. The process is known as a condensation reaction because during the reaction, water molecule is released [7].

In 2007 experimental and theoretical study for aspartic acid side chain effect was done by Rožman He suggested the procedure to progressed by a complex one-step mechanism including proton transfer (from side-chain carboxylic group to backbone amide group), bond formation (between deprotonated carboxylic group and carbon atom of the backbone carbonyl) [8].

1n 2016 Kandemirli and Sayiner studied the interaction between phenyl alanine and ceftriaxone. Their study focused on the concerted and stepwise mechanisms for the peptide bond formation for amino group of ceftriaxone with carboxyl group of phenylalanine, and amino group of phenylalanine with carboxyl group of ceftriaxone by using semi-empiricalparameterization method (PM6) and they indicated the transition state, activation energy of this interaction [7]. Our study focused on the interaction of carboxyl group of aspirin with amino group of AA. The study was administered to estimate the interaction of glycine as AA to aspirin.

The main aim of the current study is to understand the interaction glycine with aspirin, and to indicate the reaction mechanism, energy of reaction and energy of activation of formation peptide bonds and an electronic structure (orders of the broken off and formed bonds). In this work, the mechanism of the reaction between the aspirin and glycine calculated with density functional theory are presented

\section{COMPUTATIONAL METHODOLOGY}

All the reactants, products and transition states have been optimized within density functional theory (DFT) framework, by using the B3LYP functional with the 6-31G(d, p) basis set. This functional is based on Becke's three-parametrization adiabatic connection method (ACM) and consists of a combination of Slater [9] Hartree-Fock, [10] and Becke exchange functional [11] the Vosko, Wilk, and Nusair (VWN) local correlation functional [12] and the Lee, Yang, and Parr[11] nonlocal correlation functional. It is possible to better define the polar bonds of the molecule with the basis of 6$31 \mathrm{G}(\mathrm{d}, \mathrm{p})$ which means ' $\mathrm{d}$ ' polarization functions in heavy atoms and the addition of ' $p$ 'polarization functions on hydrogen atoms [13,14]. Intrinsic Reaction Coordinate IRC proposed by Fukui in 1970 as a pathway of chemical reactions, the steepest descent path weighted predominantly on the potential energy surface (PES), starting from the transition (TS), ie the first rank saddle point was used. The IRC have been computed automatically using intrinsic reaction coordinate (IRC), following algorithms. Starting from nonstationary structures, the mass - weighted steepest descent path is called meta - IRC. The calculations have been carried out with the GAUSSIAN 09 series of programs [15]

\section{RESULT AND DISCUSSION}

The stepwise mechanisms for the bond formation are illustrated with the optimized structures of the reactants glycine+ aspirin (1+2), the transition state 1 (TS1), intermediate (IN), transition state 2 (TS2) and products $\left(3+\mathrm{H}_{2} \mathrm{O}\right)$ calculated with B3LYP/6-31G(d, p) level in Figure 3.
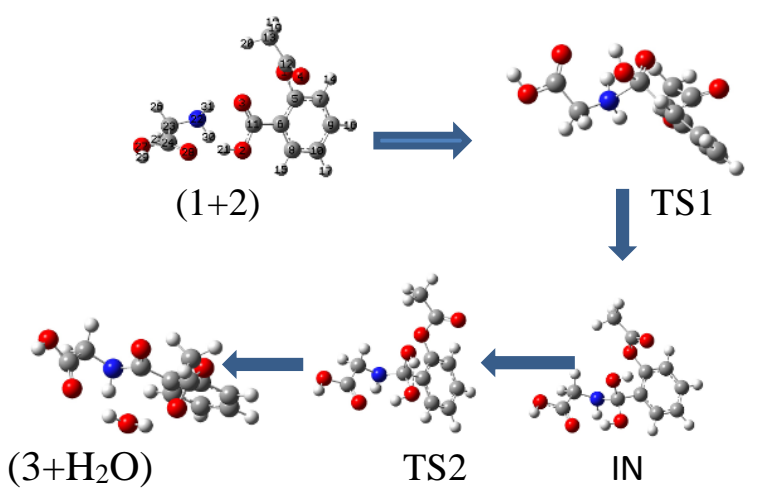

Figure. 3 Reaction mechanism between aspirin and glycine.

Electrostatic potential maps enable us to visualize the charge distributions of molecules and charge related properties of molecules and also allow us to visualize the size and shape of molecules. Optimized form, HOMO, LUMO and MEP surfaces of aspirin and glycine far away 3.00 $\AA$ from each other, IN, TS1, and TS2 and products with the water far away $2.50 \AA$ calculated with B3LYP/6-31+G(d, p) level are plotted 
in Figure 4. MEP surfaces give information about electronegative and positive charge region of the molecules.

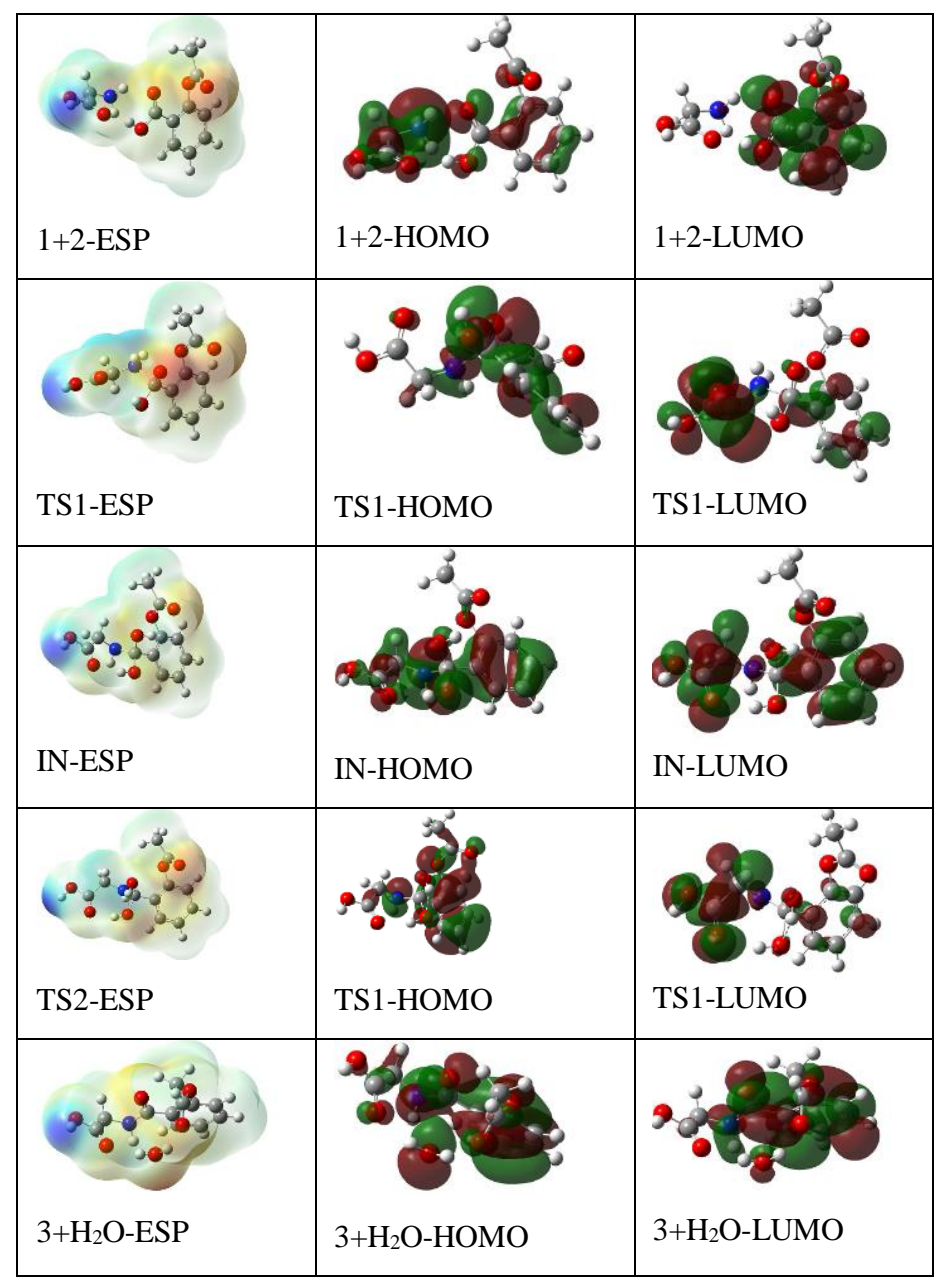

Figure 4 ESP, HOMO, LUMO of reactants, intermediate, transition states and products.

In this reaction we considered the reaction between the HOMO of glycine and the LUMO of aspirin. In Figure 5, The obtained molecular structures, HOMO LUMO of the 1, 2 and 3 molecules by DFT/B3LYP/6-31G(d, p) are given. HOMO of glycine is mainly localized on the $\mathrm{NH}_{2}$ group and LUMO of the aspirin distributed on the phenyl ring and carbonyl group attached to phenyl ring. For the B3LYP success was achieved when the interaction of glycine $\mathrm{N}$ lone pair with the carbonyl center of aspirin was performed. When considering both the charge interaction and most likely the HOMO/LUMO interactions led to the conclusion that glycine reacts with aspirin by nucleophilic attack of glycine nitrogen (N22) lone pair on the carbonyl carbon $\mathrm{C} 11$ of aspirin considered the reaction between the HOMO of glycine and the LUMO of aspirin.

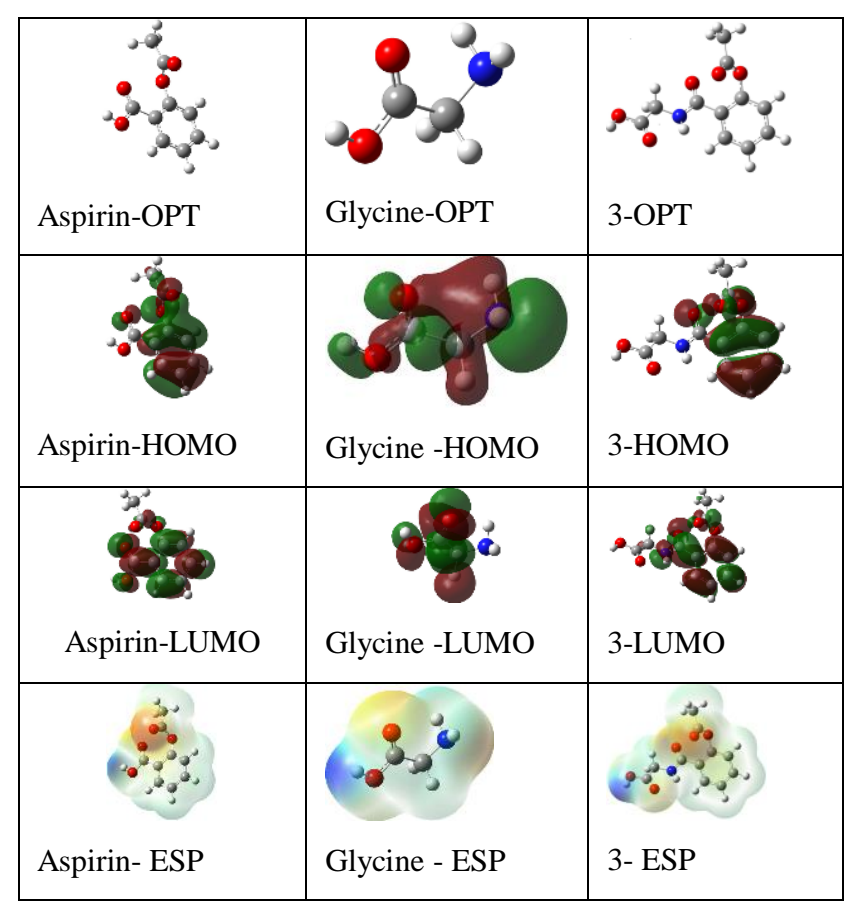

Figure 5 The obtained molecular structures, HOMO LUMO of the 1,2 and 3 molecules by DFT/B3LYP/6-31+G(d, p).

Sum of electronic and thermal Enthalpies (STH) for the aspirin and glycine $(1+2)$ in the far away from each other, transition states TS1 and TS2, intermediate and result product (3) in gas media are presented in Figure 6.

Reactants in the Figure 4 reach the products via two transition states and one intermediate. STH value for TS1 and TS2 were collected from the results of PES analysis by performing scan on the intrinsic reaction coordinate using the B3LYP/631G (d, p) method. An IRC calculation starts at the saddle point and follows the path in both directions from the TS, optimizing the geometry of the system along the way. In this way two minima on the PES are surely connected by a path passing through the TS.

It can be seen from the Figure 6 that reaction was endothermic, by $4.0 \mathrm{Kcal} \mathrm{mol}^{-1}$. From figure 6 the transition (TS1) represent a high energy species in which the activation energies are $35 \mathrm{Kcal} \mathrm{mol}^{-1}$. While for TS2 activation energies are $20 \mathrm{Kcal} / \mathrm{mol}$. In vibrational analysis a negative imaginary frequency, which is the first order saddle, is characteristic of an ordinary TS for transitional states (TS. The imaginary frequencies for TS1 and TS2 in the stepwise process are -1605 $\mathrm{cm}^{-1}$ and $-1620 \mathrm{~cm}^{-1}$. 


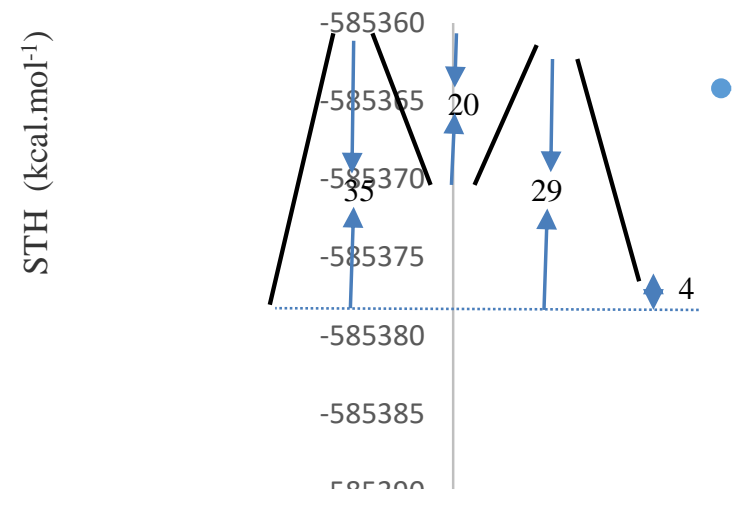

Figure 6 Reaction energy diagram.

As shown from the Figure 5, in the first step $\mathrm{N}_{22}$ atom of glycine attacks the $\mathrm{C}_{11}$ atom belonging carbonyl center of formaldehyde and a bonding occurred between the $\mathrm{N}_{22}$ and $\mathrm{C}_{11}$ $\mathrm{C}-\mathrm{N}$ bond with a transfer of hydrogen atom from $\mathrm{N}_{22}$ of glycine to a carbonyl $\mathrm{C}_{11}$ of the aspirin during the geometry optimization/energy minimization procedures to form intermediate.

The sum of electronic and thermal enthalpies (STH) of the reacting molecules glycine and aspirin $(1+2)$ being far from each other $\left(\mathrm{N}_{22}-\mathrm{C}_{11}=3.000 \AA\right)$ is $-585399 \mathrm{kcal} \mathrm{mol}^{-1}$ with the calculation B3LYP/6-31(d, p) level. The reaction coordinate involves the enlargement of the $\mathrm{N}_{22}-\mathrm{H}_{31}, \mathrm{C}_{11}-\mathrm{O}_{3}$, and $\mathrm{C}_{11}-\mathrm{O}_{2}$ distances and the shortening of $\mathrm{N}_{22}-\mathrm{C}_{11}$.

As it is seen in Table 1, the distance between the carbon and nitrogen involved in the formation of the new $\mathrm{N}-\mathrm{C}$ single bond in TS1 and in IN is found to be $1.715 \AA$ and $1.464 \AA$. As the bond between $\mathrm{N}_{22}-\mathrm{H}_{31}$ the reacting molecules glycine and aspirin $(1+2)$. being far from each other, was $1.014 \AA$ it was found, $1.030 \AA$ and 3.117 for TS1 and IN, respectively.

Table 1 Bond Lengths of the reactants, the two transition states and one intermediate, and for products

\begin{tabular}{|c|c|c|c|c|c|}
\hline \multirow{2}{*}{$\begin{array}{c}\text { Atom } \\
\text { Nos }\end{array}$} & $1+2$ & TS1 & IN & TS2 & $3+\mathrm{H}_{2} \mathrm{O}$ \\
\cline { 2 - 6 } & \multicolumn{5}{|c|}{ BOND LENGTHS $(\AA)$} \\
\cline { 2 - 6 } & 3.000 & 1.715 & 1.464 & 1.401 & 1.392 \\
\hline $\mathrm{N}_{22}-\mathrm{C}_{11}$ & 1.492 & 1.531 & 1.537 & 1.521 & 1.504 \\
\hline $\mathrm{C}_{11}-\mathrm{C}_{6}$ & 1.223 & 1.274 & 1.413 & 1.376 & 1.228 \\
\hline $\mathrm{C}_{11}-\mathrm{O}_{3}$ & 1.341 & 1.408 & 1.403 & 1.691 & 1.228 \\
\hline $\mathrm{C}_{11}-\mathrm{O}_{2}$ & 1.013 & 1.019 & 1.014 & 1.009 & 1.012 \\
\hline $\mathrm{N}_{22}-\mathrm{H}_{30}$ & 1.014 & 1.030 & 3.117 & 2.833 & 3.396 \\
\hline $\mathrm{N}_{22}-\mathrm{H}_{31}$ & 1.442 & 1.451 & 1.444 & 1.439 & 1.443 \\
\hline $\mathrm{N}_{22}-\mathrm{C}_{23}$ & 1.527 & 1.451 & 1.526 & 1.523 & 1.526 \\
\hline $\mathrm{C}_{23}-\mathrm{C}_{24}$ & 1.221 & 1.209 & 1.218 & 1.214 & 1.214 \\
\hline $\mathrm{C}_{24}-\mathrm{O}_{28}$ & 1.344 & 1.347 & 1.347 & 1.346 & 1.348 \\
\hline $\mathrm{C}_{24}-\mathrm{O}_{27}$ & 0.991 & 0.972 & 0.977 & 0.975 & 0.971 \\
\hline $\mathrm{O}_{2}-\mathrm{H}_{21}$ & 3.000 & 3.262 & 3.151 & 3.219 & 3.059 \\
\hline
\end{tabular}

\begin{tabular}{|c|c|c|c|c|c|}
\hline $\mathrm{O}_{3}-\mathrm{H}_{30}$ & 2.022 & 1.814 & 0.968 & 0.986 & 3.172 \\
\hline $\mathrm{O}_{3}-\mathrm{H}_{31}$ & 1.405 & 1.400 & 1.400 & 1.398 & 1.404 \\
\hline $\mathrm{C}_{6}-\mathrm{C}_{8}$ & 1.409 & 1.401 & 1.403 & 1.401 & 1.407 \\
\hline $\mathrm{C}_{6}-\mathrm{C}_{5}$ & 1.385 & 1.401 & 1.401 & 1.393 & 1.394 \\
\hline $\mathrm{C}_{5}-\mathrm{O}_{1}$ & 1.381 & 1.389 & 1.364 & 1.379 & 1.361 \\
\hline $\mathrm{O}_{1}-\mathrm{C}_{12}$ & 1.203 & 1.200 & 1.209 & 1.203 & 1.211 \\
\hline $\begin{array}{c}\text { imaginary } \\
\text { freq }\left(\mathrm{cm}^{-1}\right)\end{array}$ & & -1605 & & -1620 & \\
\hline
\end{tabular}

From Table 2, Mulliken charge of atom $\mathrm{C}_{11}$ at $1+2$, TS1 and IN for calculation with B3LY/6-31G(d, p) are 0,580 $\overline{\mathrm{e}}$, $0,595 \overline{\mathrm{e}}, 0,576 \overline{\mathrm{e}}$, respectively; charges on atom $\mathrm{N}_{22}$ at $1+2$, TS1 and IN are $-0,608 \overline{\mathrm{e}},-0,560 \overline{\mathrm{e}},-0,494 \overline{\mathrm{e}}$. due to different orbitals overlapping.

The intra-molecular interaction of the intermediate state proceeds to form the second transition state (TS2) via the $\mathrm{N}_{22}$ $\mathrm{C}_{11}$ bond formation and $\mathrm{H}_{2} \mathrm{O}$ elimination via $\mathrm{C}-\mathrm{O}$ bond cleavage.

Decrease of about $0.251 \AA$ in $\mathrm{N}_{22}-\mathrm{C}_{11}$ bond length as the reaction proceeds from TS1 to IN was observed and also a decrease of $0.063 \AA$ was observed as the reaction proceeds from IN to TS2. The bond length also increased with $0.139 \AA$ in $\mathrm{C} 11-\mathrm{O} 3$ as the reaction proceed from TS1 to IN while a decrease of $0.037 \AA$ was observed as the reaction proceed to TS2.

Table 2 Mulliken charges of the reactants, the two transition states, one intermediate, and for products.

\begin{tabular}{|c|c|c|c|c|c|}
\hline \multirow{2}{*}{$\begin{array}{c}\text { Atom } \\
\text { Nos }\end{array}$} & $1+2$ & TS1 & IN & TS2 & $3+\mathrm{H}_{2} \mathrm{O}$ \\
\cline { 2 - 6 } & \multicolumn{5}{|c|}{ Mulliken charges(e- } \\
\hline $\mathrm{N}_{22}$ & $-0,608$ & $-0,560$ & $-0,494$ & $-0,485$ & $-0,535$ \\
\hline $\mathrm{C}_{11}$ & 0,580 & 0,595 & 0,576 & 0,553 & 0,586 \\
\hline $\mathrm{C}_{6}$ & 0,060 & 0,080 & 0,038 & 0,044 & 0,108 \\
\hline $\mathrm{O}_{3}$ & $-0,517$ & $-0,642$ & $-0,566$ & $-0,553$ & $-0,541$ \\
\hline $\mathrm{O}_{2}$ & $-0,532$ & $-0,562$ & $-0,564$ & $-0,646$ & $-0,675$ \\
\hline $\mathrm{H}_{30}$ & 0,247 & 0,303 & 0,249 & 0,266 & 0,283 \\
\hline $\mathrm{H}_{31}$ & 0,280 & 0,316 & 0,329 & 0,338 & 0,335 \\
\hline $\mathrm{C}_{23}$ & $-0,129$ & $-0,100$ & $-0,118$ & $-0,127$ & $-0,124$ \\
\hline $\mathrm{C}_{24}$ & 0,567 & 0,582 & 0,580 & 0,577 & 0,599 \\
\hline $\mathrm{O}_{28}$ & $-0,492$ & $-0,451$ & $-0,488$ & $-0,468$ & $-0,478$ \\
\hline $\mathrm{O}_{27}$ & $-0,462$ & $-0,477$ & $-0,471$ & $-0,470$ & $-0,473$ \\
\hline $\mathrm{H}_{21}$ & 0,364 & 0,317 & 0,332 & 0,323 & 0,327 \\
\hline $\mathrm{C}_{8}$ & $-0,121$ & $-0,128$ & $-0,122$ & $-0,111$ & $-0,127$ \\
\hline $\mathrm{C}_{5}$ & 0,304 & 0,283 & 0,306 & 0,315 & 0,277 \\
\hline $\mathrm{O}_{1}$ & $-0,525$ & $-0,566$ & $-0,519$ & $-0,534$ & $-0,506$ \\
\hline
\end{tabular}


Published Online May 2020 in IJEAST (http://www.ijeast.com)

\begin{tabular}{|c|c|c|c|c|c|}
\hline $\mathrm{C}_{12}$ & 0,604 & 0,616 & 0,601 & 0,597 & 0,616 \\
\hline $\mathrm{O}_{4}$ & $-0,447$ & $-0,434$ & $-0,476$ & $-0,444$ & $-0,506$ \\
\hline $\mathrm{PZ}$ & $-0,095$ & $-0,184$ & $-0,094$ & $-0,103$ & 0,001 \\
\hline
\end{tabular}

Table 3 presents the highest occupied molecular orbital (HOMO) energy, the lowest unoccupied molecular orbital (LUMO) energy, HOMO and LUMO energy gap and parameters related with HOMO and LUMO energy of $1+2$, TS1, IN, TS2, $3+\mathrm{H}_{2} \mathrm{O}$, glycine, aspirin and the molecule 3 without water in the gas phase calculated at the DFT/B3LYP level in the $6-31 \mathrm{G}(\mathrm{d}, \mathrm{p})$ basis set.

Table 3 Some descriptors for $1+2$, TS1, IN, TS2, $3+\mathrm{H}_{2} \mathrm{O}, 1,2$, and 3.(energy unit is eV)

\begin{tabular}{|c|c|c|c|c|c|c|c|c|}
\hline $\begin{array}{c}\text { P } \\
\mathrm{C}\end{array}$ & $1+2$ & TS1 & IN & TS2 & $3+\mathrm{H}_{2} \mathrm{O}$ & 1 & 2 & 3 \\
\hline $\begin{array}{c}\mathrm{E}_{\text {LUMO }} \\
(\mathrm{eV})\end{array}$ & -1.37 & -0.55 & -0.23 & -0.44 & -1.05 & 0.18 & -1.49 & -0.95 \\
\hline $\begin{array}{c}\mathrm{E}_{\text {HOMO }} \\
(\mathrm{eV})\end{array}$ & -6.57 & -5.90 & -6.26 & -6.58 & -6.70 & -6.79 & -6.93 & -6.71 \\
\hline $\begin{array}{c}\Delta \mathrm{E} \\
(\mathrm{eV})\end{array}$ & 5.20 & 5.35 & 6.03 & 6.14 & 5.65 & 6.97 & 5.44 & 5.76 \\
\hline $\begin{array}{c}\eta \\
(\mathrm{eV})\end{array}$ & 2.60 & 2.68 & 3.02 & 3.07 & 2.83 & 3.49 & 2.72 & 2.88 \\
\hline $\begin{array}{c}\mathrm{S} \\
(\mathrm{eV})^{-1}\end{array}$ & 0.19 & 0.19 & 0.17 & 0.16 & 0.18 & 0.14 & 0.18 & 0.17 \\
\hline $\begin{array}{c}\chi \\
(\mathrm{eV})\end{array}$ & 3.97 & 3.23 & 3.25 & 3.51 & 3.88 & 3.31 & 4.21 & 3.83 \\
\hline $\begin{array}{c}\mu \\
(\mathrm{eV})\end{array}$ & -3.97 & -3.23 & -3.25 & -3.51 & -3.88 & -3.31 & -4.21 & -3.83 \\
\hline $\begin{array}{c}\omega \\
(\mathrm{eV})\end{array}$ & 3.03 & 1.94 & 1.75 & 2.01 & 2.66 & 1.57 & 3.26 & 2.55 \\
\hline $\begin{array}{c}\Delta \mathrm{E}_{\mathrm{n}} \\
(\mathrm{eV})\end{array}$ & 0.36 & 0.06 & 0.01 & 0.03 & 0.20 & 0.00 & 0.41 & 0.16 \\
\hline $\begin{array}{c}\Delta \mathrm{E}_{\mathrm{e}} \\
(\mathrm{eV})\end{array}$ & 8.30 & 6.51 & 6.50 & 7.05 & 7.95 & 6.61 & 8.83 & 7.82 \\
\hline & $\mathrm{C}(\mathrm{Compounds}), \mathrm{P}(\mathrm{parameters})$ & & \\
\hline
\end{tabular}

According to Koopman's theorem [16] parameters such as chemical hardness, softness $[17,18]$ electronegativity and chemical potential, electrophilicity [19] can be defined as following

$$
\begin{aligned}
\eta & =\frac{1}{2}\left(\mathrm{E}_{\text {LUMO }}-\mathrm{E}_{\text {HOMO }}\right) \\
\sigma & =\frac{1}{\eta} \\
\mu & =-\chi=\frac{1}{2}\left(E_{\text {HOMO }}+E_{\text {LUMO }}\right) \\
\omega & =\frac{\mu^{2}}{2 \eta}
\end{aligned}
$$

Nucleofugality $\Delta \mathrm{E}_{\mathrm{n}}$ and electrofugality $\Delta \mathrm{E}_{\mathrm{e}}$ proposed by Ayers and co-workers [20] define nucleophilic and electrophilic capabilities of a leaving group and are calculated as following.

$$
\begin{aligned}
& \Delta E_{n}=-A+\omega=\frac{(\mu+\eta)^{2}}{2 \eta} \\
& \Delta E_{e}=I+\omega=\frac{(\mu-\eta)^{2}}{2 \eta}
\end{aligned}
$$

The energy of HOMO and the energy of LUMO indicate the electron donating and the ability of the molecule to accept electrons respectively [21]. $\mathrm{E}_{\mathrm{HOMO}}$ for $1+2$, TS1, IN, TS2, $3+\mathrm{H}_{2} \mathrm{O}, 1,2$, and 3 calculated with the B3LYP/6-31G(d, p) level are -6,57 eV, -5,90 eV, -6,26 eV, -6,58 eV, -6,70 eV, $6,79 \mathrm{eV},-6,93 \mathrm{eV}-6,71 \mathrm{eV}$ respectively and $\mathrm{E}_{\mathrm{LUMO}}-1,37 \mathrm{eV},-$ $0,55 \mathrm{eV},-0,23 \mathrm{eV},-0,44 \mathrm{eV},-1,05 \mathrm{eV}, 0,18 \mathrm{eV},-1,49 \mathrm{eV},-$ $0,95 \mathrm{eV}$. Khan et al. [22] calculated HOMO energy of Aspirin in gas phase, water, Methanol, ethanol and n-octanol medai and were found as $-7.055 \mathrm{eV},-6.986 \mathrm{eV},-6.983 \mathrm{eV},-6.956$ $\mathrm{eV},-6.963 \mathrm{eV}$, respectively. As seen from the Table 2, the energy of HOMO for aspirin is less than the molecule 3. The half of the gap between the HOMO and LUMO orbital energy is called as global hardness and associated with the stability of the chemical. The hardness in TS1 and IN are found to be as $2.68 \mathrm{eV}, 3.02 \mathrm{eV}$. The hardness of the molecule 3 is bigger than that of $1+2$

The tendency of the molecule to accept electrons is defined as electrophilicity index $(\omega)$ which explain the electrophilic and nucleophilic behaviour of molecules and calculated with the formula given in Equation 4 [23]. As seen from the Equation 4, if a molecule has high chemical potential and low chemical hardness, it means it is a good electrophile. Electrophilicity index of aspirin is bigger than that of glycine.

Table 4 presents the non-linear optical properties of $1+2$, TS1, IN, TS2, $3+\mathrm{H}_{2} \mathrm{O}, 1,2$, and 3 molecule in the gas phase. The properties computed and reported are dipole moment $\left(\mu_{\text {tot }}\right)$, polarizability $(<\alpha>)$, anisotropic polarizability $(\Delta \alpha)$ and hyperpolarizability $\left(\beta_{\text {tot }}\right)$. The values of the polarizability and first hyperpolarizability tensors were computed and converted into electrostatic units where (for $\alpha: 1 \mathrm{au} .=0.1482 \times 10^{-24} \mathrm{esu}$ ), and (for $\beta$ : 1 au. $=8.6393 \times 10^{-33} \mathrm{esu}$ ) [24].

Table 4 the non-linear optical properties of $1+2$, TS1, IN, TS2, $3+\mathrm{H}_{2} \mathrm{O}, 1,2$, and 3 molecule in the gas phase.

\begin{tabular}{|c|c|c|c|c|}
\hline \multicolumn{1}{|c|}{$\mathrm{C}^{\mathrm{P}}$} & $\begin{array}{l}\mu \\
\text { Debye }\end{array}$ & $\begin{array}{c}\alpha \times 10^{-24} \\
\text { esu }\end{array}$ & $\begin{array}{c}\Delta \alpha \times 10^{-24} \\
\text { esu }\end{array}$ & $\begin{array}{c}\beta \times 10^{-30} \\
\text { esu }\end{array}$ \\
\hline $1+2$ & 1.11 & 20.53 & 11.69 & 1.93 \\
\hline $\mathrm{TS} 1$ & 2.69 & 20.31 & 9.07 & 1.69 \\
\hline $\mathrm{IN}$ & 1.25 & 20.00 & 11.25 & 0.45 \\
\hline $\mathrm{TS} 2$ & 2.08 & 20.30 & 10.31 & 0.99 \\
\hline $3+\mathrm{H}_{2} \mathrm{O}$ & 0.71 & 20.51 & 11.74 & 1.35 \\
\hline 1 & 0.49 & 4.94 & 1.85 & 0.83 \\
\hline 2 & 0.79 & 14.96 & 10.88 & 1.41 \\
\hline 3 & 0.48 & 19.51 & 12.28 & 0.54 \\
\hline \multicolumn{5}{|c|}{$\mathrm{C}$ ( Compounds), P(parameters) } \\
\hline
\end{tabular}

The dipole moment in a molecule is an important feature used to study the intermolecular interactions that mainly include unbound type dipole-dipole interactions, because the 


\section{International Journal of Engineering Applied Sciences and Technology, 2020 \\ Vol. 5, Issue 1, ISSN No. 2455-2143, Pages 67-73 \\ Published Online May 2020 in IJEAST (http://www.ijeast.com)}

higher the dipole moment means the stronger the intermolecular interactions, the dipole moment of TS1 and $\mathrm{TS} 2$ is the highest as seen from the Table 4. Mean polarizability values of $1+2$, TS1, IN, TS2 and $3+\mathrm{H}_{2} \mathrm{O}$ are the nearly the same. The polarizability value of the molecule 3 is bigger than that of aspirin. Hyperpolarizibility of TS1 is less than that of molecule $1+2$ and bigger than that of IN. First hyperpolarisibilit value of molecule 3 are less than that of aspirin.

\section{CONCLUSION}

The reaction is nucleophilic in nature in which the $\mathrm{N}_{22}$ lone pair of glycine attacks the carbonyl carbon $\left(\mathrm{C}_{11}\right)$ of aspirin to form aspirin-glycine adduct. The HOMO LUMO energies, energy gap and the parameters related to energy gap, dipole moment, the anisotropic polarizability, first hyperpolarisibilit value were calculated for $1+2$, TS1, IN, TS2, $3+\mathrm{H}_{2} \mathrm{O}, 1,2$, and 3 molecule in the gas phase. The HOMO-LUMO energy calculations show that the energy gab increases with the combination of aspirin-glycine.

\section{REFERENCE}

1. Mirošević Skvrce, N., Macolić Šarinić, V., Mucalo, I., Krnić, D., Božina, N., \& Tomić, S. (2011). Adverse drug reactions caused by drug-drug interactions reported to Croatian Agency for Medicinal Products and Medical Devices: a retrospective observational study. Croatian medical journal, 52(5), 604-614.

2. Sharma, M., Pathak, M., Roy, B., Jain, L., Yadav, N., Sarkar, B., .\& Sharma, M. (2010). Quantitative estimation of aspirin in various drugs: UV-Vis absorption spectroscopy and colorimetric studies. Delhi University Journal of Undergraduate Research and Innovation, 4, 157-62.

3. Navarro, S. L., Saracino, M. R., Makar, K. W., Thomas, S. S., Li, L., Zheng, Y., \& Lampe, J. W. (2011). Determinants of aspirin metabolism in healthy men and women: effects of dietary inducers of UDPglucuronosyltransferases. Lifestyle Genomics, 4(2), 110118.

4. Vane, J. R., \& Botting, R. M. (2013). The William Harvey Research Institute, St Bartholomew's and the Royal London School of Medicine and Dentistry, Queen Mary and Westfield College, 433, 131.

5. Murtaza, G. H. U. L. A. M., Karim, S., Najam-ul-Haq, M. U. H. A. M. M. A. D., Ahmad, M., KHAN, S. A., ASAD, M. H. H. B., \& HUSSAIN, I. (2014). Interaction analysis of aspirin with selective amino acids. Acta poloniae pharmaceutica, 71(1), 139-143.

6. Wang, J., Zhang, C. J., Zhang, J., He, Y., Lee, Y. M., Chen, S., ... \& Lin, Q. (2015). Mapping sites of aspirininduced acetylations in live cells by quantitative acid- cleavable activity-based protein profiling (QAABPP). Scientific reports, 5, 7896.

7. Sayiner, H. S., \& Kandemirli, F. (2016). The Reaction Mechanism Study of Ceftriaxone and Phenylalanine. Journal of International Research in Medical and Pharmaceutical Sciences, 83-90.

8. Rožman, M. (2007). Aspartic acid side chain effectExperimental and theoretical insight. Journal of the American Society for Mass Spectrometry, 18(1), 121127.

9. Slater, J. C. (1974). Quantum Theory of Molecular and Solids. The self-Consistent Field for Molecular and solids, 4.

10. Fock, V. (1930). Näherungsmethode zur Lösung des quantenmechanischen Mehrkörperproblems. Zeitschrift für Physik, 61(1-2), 126-148.

11. Dobson, J. F., Vignale, G., \& Das, M. P. (Eds.). (2013). Electronic density functional theory: recent progress and new directions. Springer Science \& Business Media.

12. Vosko, S. H., Wilk, L., \& Nusair, M. (1980). Accurate spin-dependent electron liquid correlation energies for local spin density calculations: a critical analysis. Canadian Journal of physics, 58(8), 1200-1211.

13. Lee, C., Yang, W., \& Parr, R. G. (1988). Development of the Colle-Salvetti correlation-energy formula into a functional of the electron density. Physical review B, 37(2), 785 .

14. Petersson, G. A., \& Al-Laham, M. A. (1991). A complete basis set model chemistry. II. Open-shell systems and the total energies of the first-row atoms. The Journal of chemical physics, 94(9), 6081-6090.

15. Frisch, M. J.; Trucks, G. W.; Schlegel, H. B.; Scuseria, G. E.; Robb, M. A.; Cheeseman, J. R.; Scalmani, G.; Barone, V.; Mennucci, B.; Petersson, G. A.; Nakatsuji, H.; Caricato, M.; Li, X.; Hratchian, H. P.; Izmaylov, A. F.; Bloino, J.; Zheng, G.; Sonnenberg, J. L.; Hada, M.; Ehara, M.; Toyota, K.; Fukuda, R.; Hasegawa, J.; Ishida, M.; Nakajima, T.; Honda, Y.; Kitao, O.; Nakai, H.; Vreven, T.; Montgomery, J. A., Jr.; Peralta, J. E.; Ogliaro, F.; Bearpark, M.; Heyd, J. J.; Brothers, E.; Kudin, K. N.; Staroverov, V. N.; Kobayashi, R.; Normand, J.; Raghavachari, K.; Rendell, A.; Burant, J. C.; Iyengar, S. S.; Tomasi, J.; Cossi, M.; Rega, N.; Millam, J. M.; Klene, M.; Knox, J. E.; Cross, J. B.; Bakken, V.; Adamo, C.; Jaramillo, J.; Gomperts, R.; Stratmann, R. E.; Yazyev, O.; Austin, A. J.; Cammi, R.; Pomelli, C.; Ochterski, J. W.; Martin, R. L.; Morokuma, K.; Zakrzewski, V. G.; Voth, G. A.; Salvador, P.; Dannenberg, J. J.; Dapprich, S.; Daniels, A. D.; Farkas, Ö.; Foresman, J. B.; Ortiz, J. V.; Cioslowski, J.; Fox, D. J. Gaussian, Inc., Wallingford CT, 2009.

16. Koopmans, T. (1933). Ordering of wave functions and eigenenergies to the individual electrons of an atom. Physica, 1, 104-113. 
17. Yang, W., Lee, C., \& Ghosh, S. K. (1985). Molecular softness as the average of atomic softnesses: Companion principle to the geometric mean principle for electronegativity equalization. The Journal of Physical Chemistry, 89(25), 5412-5414.

18. Yang, W., \& Parr, R. G. (1985). Hardness, softness, and the fukui function in the electronic theory of metals and catalysis. Proceedings of the National Academy of Sciences, 82(20), 6723-6726.

19. Parr, R. G., Szentpaly, L. V., \& Liu, S. (1999). Electrophilicity index. Journal of the American Chemical Society, 121(9), 1922-1924.

20. Ayers, P. W., Anderson, J. S., \& Bartolotti, L. J. (2005). Perturbative perspectives on the chemical reaction prediction problem. International Journal of Quantum Chemistry, 101(5), 520-534.

21. Larabi, L., Harek, Y., Benali, O., \& Ghalem, S. (2005). Hydrazide derivatives as corrosion inhibitors for mild steel in $1 \mathrm{M} \mathrm{HCl}$. Progress in Organic Coatings, 54(3), 256-262.

22. Khan, M. F., Rashid, R. B., Rahman, M. M., Al Faruk, M., Rahman, M. M., \& Rashid, M. A. (2017). Effects of solvent polarity on solvation free energy, dipole moment, polarizability, hyperpolarizability and molecular reactivity of aspirin. Int. J. Pharm. Pharm. Sci, 9(2), 217-221.

23. Parr, R. G., Szentpaly, L. V., \& Liu, S. (1999). Electrophilicity index. Journal of the American Chemical Society, 121(9), 1922-1924.

24. Ahmed, A. B., Feki, H., Abid, Y., Boughzala, H., \& Mlayah, A. (2008). Structural, vibrational and theoretical studies of 1-histidine bromide. Journal of Molecular Structure, 888(1-3), 180-186. 